\title{
Qualitative and Quantitative Evaluation Protocol of Baccharis Seed Germination
}

\author{
María Alejandra Moreno-Pizani ${ }^{1}$, Asdrubal Jesus Farias-Ramirez ${ }^{1}$, Hugo Thaner dos Santos ${ }^{2}$, \\ Ana Dionisia da Luz Coelho Novembre ${ }^{3}$, Lorena Isabel Guevara-Orozco ${ }^{4}$, Franklin Paredes-Trejo ${ }^{5}$, \\ Fábio Ricardo Marin ${ }^{1}$, Nildo da Silva Dias $^{6} \&$ Patricia Angélica Alves Marques ${ }^{1}$ \\ ${ }^{1}$ Biosystems Engineering Department, University of São Paulo, Piracicaba, SP, Brazil \\ ${ }^{2}$ Agricultural Engineering Department, Federal University of Viçosa, Viçosa, MG, Brazil \\ ${ }^{3}$ Crop Science Department, University of São Paulo, Piracicaba, SP, Brazil \\ ${ }^{4}$ Independent Researcher, Rua Teófilo Soares Gomes 866, Jardim Social, Curitiba, PR, Brazil \\ ${ }^{5}$ Institute of Atmospheric Sciences, Federal University of Alagoas, A. C. Simões Campus, Brazil \\ ${ }^{6}$ Agricultural Science Center, Federal Rural University of the Semi-Arid, Mossoró, Rio Grande do Norte, Brazil \\ Correspondence: María Alejandra Moreno-Pizani, Biosystems Engineering Department, University of São Paulo, \\ Avenida Pádua Dias, 11-São Dimas, Piracicaba, SP, 13418-900, Brazil. Tel: 55-193-447-8505. E-mail: \\ morenom76@gmail.com
}

Received: November 18, 2018

doi:10.5539/jas.v11n3p421
Accepted: December 21, 2018

Online Published: February 15, 2019

URL: https://doi.org/10.5539/jas.v11n3p421

\begin{abstract}
Baccharis trimera (Less.) DC (E1) and Baccharis crispa Spreng. (E2) possess potential antimicrobial and anti-inflammatory properties. Qualitative and quantitative information on seed germination on these species is scarce. The objective of this investigation was to establish a protocol for evaluating seed germination of E1 and E2 and to analice the scoring and curve fitting by the Germinator package, for different periods of germination were between 0.93 and 0.99 . Both species showed differences in germinability and mean germination time, 27 days for E1 and 20 days for E2. The germination dispersion showed that E1 germination was homogeneous, with differences in growth pattern, whereas the results on germination of E2. The mean speed of germination determined with the experimental data was close to the values obtained by the Germinator package, with a maximum germination of more than $34 \%$, proving that the software was efficient for evaluating germination.
\end{abstract}

Keywords: carqueja, eclosion, medicinal plant, radical, emergence

\section{Introduction}

The plants of the family Asteraceae have been widely studied, some species from the genus Baccharis sp. are used in popular medicine and phytotherapy. Baccharis trimera (Less.) DC. is a plant native from South America and is found in southern Brazil, northern Argentina, Paraguay, Bolivia, and Uruguay (Abad \& Bermejo, 2007; de Oliveira et al., 2012).

In Brazil, the Baccharis species, which have cladodes are popularly called "Carqueja" in Brazilian Portuguese, and they are used due to its medicinal properties, digestive, antimicrobial and anti-inflammatory effects, treatment of diabetes, liver dysfunctions and rheumatism (Rabelo \& Costa, 2018; Fukuda, Ohkoshi, Makino, \& Fujimoto, 2006; Gené et al., 1996; Oliveira, Endringer, Amorim, Brandão, \& Coelho, 2005; Torres et al., 2000). Their chemical constituents are used in the synthesis of drugs and in the beverage industry due to the bitter taste (Campos et al., 2016).

Baccharis crispa Spreng. has a wide distribution in Brazil, is found in the southeastern (Minas Gerais, Rio de Janeiro, São Paulo) and southern (Paraná, Santa Catarina, Rio Grande do Sul) regions, in the Cerrado, Atlantic Forest and Pampa Biomes. This species exhibits erect stem, panicles 0.15-0.40 $\mathrm{m}$ in length, spiciform branches 0.03-0.20 m, female corolla with truncated or irregularly denticulated apex and cypselas 1.0-1.5 mm. B. trimera has glandular trichomes and B. crispa glandular and tector, with smooth cuticle on both (Budel et al., 2012).

Dioecious plants have difficulties in sexual propagation because of the great genetic variability resulting from the cross fertilization during the long time of production of the seedlings, and by the small size of the seeds in 
the collection and the sowing (Abad \& Bermejo, 2007). Due to the economic importance of this plant for the pharmaceutical and food industry, the Chemical, Biological and Agricultural Pluridisciplinary Research Center for Chemistry, Biology and Agriculture (CPQBA), State University of Campinas (UNICAMP), São Paulo, Brazil, developed the cultivar CPQBA-1, which has a vigorous growth and a superior dynamic germination, germination speed and synchronicity.

Studies related to methods for the analysis of seeds of Brazilian medicinal species have recently been carried out to obtain information on the required conditions for seed germination of many species including Elephantopus mobillis; Eupatorium laevigatum; Mikania cordifolia; Senecio oxyphyllus; Trixis praestans, Eclipta alba, according to the mean temperature for germination, the species could be ranked in: warmer-treatmets at $30{ }^{\circ} \mathrm{C}$; colder-between 20 at $25^{\circ} \mathrm{C}$ (Tagetes minuta, and in Senecio heterotrichius; S. selloi; Stenachaenium campestre; Symphyopappus casarettoi and Vernonia nudiflora), as determined in the mean time for germination, the species could be ranked in: fast-less than 5 days-(Baccharis trimera; Eclipta alba; Elephantopus mollis; Stenachaenium campestre and Vernonia nudiflora); intermediate-between 5 and 10 days-(Eupatorium laevigatum; Mikania cordifolia and Tagetesminuta); slow-more than 10 days-(Senecio heterotrichius; S. oxyphyllus; S. selloi; Symphyopappus casarettoi and Trixis praestans), and light promoted germination for all species except in Stenachaenium campestre and Tagetesminuta, the latter being a negative photoblastic species (Ferreira, Cassol, Rosa, \& Silva, 2001).

In Brazil the Baccharis market is limited by the difficulty in quantifying the potential of seed germination and setting a protocol for accomplishment measures for small seeds, including weight, moisture degree, germination rate $(\mathrm{G})$, germintation velocity $(\mathrm{GV})$, germination speed index (GSI) and synchronization index, would be useful to facilitate the analysis of the seeds the planning of planting and commercialization.

The quantification process of the germination speed was evaluated by different means as indicated by Edwards (1932). Several indexes are also used, as the rate of germination speed, Maguire (1962) widely known in the agronomic area, used to calculate the rate of germination, the coefficient of uniformity of germination (Bewley \& Black, 1994; Heydecker, 1973; Nichols, 1968), among others, and the synchronization index, explored in the studies of Labouriau et al. (Labouriau \& Agudo, 1987; Labouriau \& Osborn, 1984; Labouriau \& Pacheco, 1978; Labouriau \& Viladares, 1976; Ranal \& Santana, 2006) Currently, there are software developed for the analysis of the germination test such as SVIS (Sako et al., 2001), Germinator (Joosen et al., 2010), SmartGrain (Tanabata et al., 2012), GerminaQuant (Ferreira Marques et al., 2015), among others.

Despite the diversity of Brazilian species, few are included in the Brazilian Rules for Seed Analysis (Melo et al., 2018), and for Baccharis seeds, the criteria for the germination test are not yet established. A recommendation from the International Seed Testing Association (ISTA) for the development of standard analysis which considers the use of descriptive statistical techniques but does not restrict the proposition of new procedures (ISTA, 2008; Santana et al., 2016).

Therefore, the objectives of this study were: (1) to evaluate seed germination of B. trimera and B. crispa, to establish adequate protocols for germination tests of these seeds and (2) to evaluate the software Germinator (Joosen et al., 2010) as a simple and efficient procedure implemented to evaluate germination to perform the germination analysis of Baccharis seeds.

\section{Method}

This research was carried out through a set of standard procedures including weight, moisture degree, germination rate $(\mathrm{G})$, germintation velocity $(\mathrm{GV})$, germination speed index (GSI) and synchronization index, Coefficient of Uniformity of Germination (CUG), Timson Index (TI) and Modified Timson Index (TIm) and adapted from the International Seed Testing Association (ISTA), as described below.

\subsection{Seed Source}

The research was conducted with two kinds of carqueja seeds. The first specie Baccharis trimera (Less.). DC. var. CPQBA-1 (E1) from the collection of medicinal plant varieties of the Chemical, Biological and Agricultural Pluridisciplinary Research Center (CPQBA), selected because the germinative dynamics and vigorous growth by massal selection with genetic control carried out for five generations, including the parental generation (García et al., 2018). The exsiccate "typus" is located at the Herbarium of the Chemical, Biological and Agricultural Pluridisciplinary Research Center CPQBA of UNICAMP and under the number 1286.

The Baccharis crispa Spreng. (E2) seeds were collected from the seed source of the experimental field at the Department of Biosystems Engineering, University of São Paulo, Campus Piracicaba, during the flowering 
period in the winter of 2016. The exsiccate "typus" is located at the UPCB Herbarium from Universidade Federal do Paraná (Paraná State University) under the number 86437.

The achenes were collected and manually cleaned, then the plant remains were removed using sieves and a stereo microscope model LFZ Dual Standard binocular with standard optics: paired WF 10× eyepieces (20) Magnification $7 \times-45 \times$, zoom factor: 6.4:1. Eye slope: $45^{\circ}$, adjustment for interpupillary distance $52-68 \mathrm{~mm}$ and dioptric compensation $\pm 5 \mathrm{~mm}$.

The degree of moisture, the mass of one thousand seeds, and the viability of the seeds were determined initially. Afterwards, the seeds of both species were stored in paper bags at $5{ }^{\circ} \mathrm{C}$ until the beginning of the analyzes, started in the June 2015 and finished in August 2016.

From the seeds of both species, the following protocol was developed for the qualitative and quantitative evaluation of carqueja seeds germination. The following evaluations were necessary considering that the seed weight and moisture degree and some germination characteristics of these species have not been reported.

\subsection{Seed Weight and Moisture Degree}

The mean seed weight (W) was determined from a sample of eight replicates of 100 seeds each, from pure live seed. Together with the determination of the mass, the degree of moisture was determined, using an analytical balance series Orion model AND HR-120 capacity $120 \mathrm{~g} \times 0.1 \mathrm{mg}$ resolution with 4 decimal digits. The results were expressed as a percentage of 1000 seeds weight, considering the limits of tolerance established for small seeds (expensive or restricted genetic material) allowed to use smaller mean samples (ISTA, 2008). Was adopted a tolerance of 0.3 between the maximum tolerated differences with the results of two replicates, considering that the seeds of the genus Baccharis are so small that the weight of a thousand seeds is less than $200 \mathrm{~g}$ (Bonner, 1984).

Considering that the weight of one thousand seeds of a sample varies according to the seed moisture degree (\% $\mathrm{U}$ ), it was determined by the dry oven method at $105 \pm 3{ }^{\circ} \mathrm{C}$ for 24 hours (ISTA, 2008), with two replicates of 0.1 $\mathrm{g}$ of seeds (Matthews et al., 2009).

\subsection{X-ray Adequacy Test}

200 seeds of each species were distributed in an acrylic plate $(18 \mathrm{~cm} \times 24 \mathrm{~cm})$ of 8 individual cells, each cell contained 25 seeds. Radiography were made by placing the acrylic plate with the seeds on an X-ray film exposed at $35 \mathrm{~cm}$ from the X-ray emission source (Faxitron X-ray model MX-20), with a radiation intensity of $23 \mathrm{kV}$ per 360 seconds, adapted the recommendations made by (Arruda et al., 2008) and (Prado-Alves et al., 2018).

The X-ray was performed to identify fully formed (TF), partially formed (FP) and non-formed (NF) seeds (ISTA, 2008). X-ray test was done since is a fast and non-destrutive test to determine morphology seed, check presencing full and empty seeds, mechanical damage and little insects (Arruda et al., 2018).

The radiographed seeds were evaluated regarding germination. The germination test was carried out on a blotting paper moistened with distilled water equivalent to 2.5 times its dry weight $\left(13 \mathrm{~cm}^{3}\right)$ in transparent plastic boxes $(11 \mathrm{~cm} \times 11 \mathrm{~cm} \times 3 \mathrm{~cm}$ ) in a germination chamber (FANEM model 347). The seeds were maintained in a photoperiod of 8 hours on artificial light (4 fluorescent lamps of $20 \mathrm{~W}$ ), at a constant temperature of $25^{\circ} \mathrm{C}$.

Due to the low quantity of fully formed seeds observed in the X-ray test and the low percentage of germination confirmed in the germination test, the weight-based germination test was carried out again for each species with adaptations in the initial test. In this case, $0.05 \mathrm{~g}$ of seeds ( 200 seed units) were randomly harvested from the homogenized pure seed portion, in 4 replicates, in the transparent plastic boxes.

The germinated seeds count were performed daily, from the 1st to the 35 th day of the test, using the criterion of normal seedlings, namely the presence of essential structures (ISTA, 2008).

The parameters analyzed were germinability $(\mathrm{G})$, coefficient of variation of time (CVt), coefficient of uniformity of germination (CUG), germination velocity (LV), Timson index (TI), modified Timson Index (TIm), and uncertainty indexes associated with the distribution of the relative frequencies of germination (U) and synchronization index $(\mathrm{Z})$.

\subsection{Germination Rate $(G)$}

The partial germination percentage and the final germination percentage were calculated $(\mathrm{G}=\mathrm{G} 1 / \mathrm{N} 1+\mathrm{G} 2 / \mathrm{N} 2$ $+\ldots+\mathrm{Gn} / \mathrm{Nn}$, where $\mathrm{Gn}=$ number of seeds with root protrusion; $\mathrm{Nn}=$ number of days of sowing) (Cardoso et al., 2013; Maguire, 1962; Rossi et al., 2018), considering the beginning of germination the emergence of a radicle. Regression curves were performed with the germination indexes, and the data were grouped at 7-day intervals, 
so the first partial germination was calculated at 7 days $(\mathrm{N} 1=7 \mathrm{~d})$, the second at 14 days $(\mathrm{N} 2=14 \mathrm{~d})$, the third at 21 days $(\mathrm{N} 3=21 \mathrm{~d})$, the fourth at 28 days $(\mathrm{N} 4=28 \mathrm{~d})$, and the fifth at 35 days $(\mathrm{N} 5=35 \mathrm{~d})$.

\subsection{Coefficient of Variation of the Germination time ( $\mathrm{CVt}$ )}

The coefficient of variation of the germination time evaluates the germination uniformity or variability in relation to the MGT (Ranal et al., 2006) (Equation 1):

$$
\mathrm{CVt}=\left(\frac{\mathrm{s}_{\mathrm{t}}}{\mathrm{t}_{\mathrm{m}}}\right) \times 100
$$

where, $\mathrm{CVt}=$ coefficient of variation of the germination time, $\%$; $\mathrm{s}_{\mathrm{t}}$ : standard deviation of germination time, days; and $\mathrm{t}_{\mathrm{m}}$ : mean germination time, days.

\subsection{Germination Velocity $(G V)$}

Germination Velocity (VE) was determined by the Equation 2 (Asgarpour et al., 2015; Bai \& Romot, 1995; Bazin et al., 2011; Cardoso et al., 2013; James, 1962; Ranal \& Santana, 2006; Souza et al., 2018):

$$
\mathrm{VE}=\frac{\sum_{\mathrm{i}}^{\mathrm{j}} \mathrm{n}_{\mathrm{i}}}{\sum_{\mathrm{i}}^{\mathrm{j}} \mathrm{t}_{\mathrm{i}}}
$$

where, $\mathrm{GV}=$ germination velocity, germinated plantule, day $^{-1}$ (no dimensions); $\mathrm{t}_{\mathrm{i}}$ : time between the beginning of the experiment and the $\mathrm{i}$-nth observation (day); ni: germinated seeds in time $\mathrm{t}_{\mathrm{i}}$; and $\mathrm{j}$ : last day of observation.

\subsection{Germination Speed Index (GSI)}

Germination Speed Index (GSI), were calculated according to the formula presented by (Melo et al., 2018; James, 1962) (Equation 3):

$$
\mathrm{IVG}=\frac{\sum_{\mathrm{i}_{\mathrm{i}}}^{\mathrm{j}} \mathrm{n}_{\mathrm{i}}}{\sum_{\mathrm{i}}^{\mathrm{j}} \mathrm{n}_{\mathrm{i}}}
$$

where, GSI = germination speed index, emerged seeds, day; ti: time between the beginning of the experiment and the $\mathrm{i}$-nth observation (day); ni: germinated seeds in time ti; and $\mathrm{j}$ : last day of observations.

\subsection{Mean Germination Time}

The mean germination time is a periodicity, defined as the multiplicative inverse of the mean germination time, (Bai \& Romot, 1995; Bazin et al., 2011; Cardoso et al., 2013; Melo et al., 2018; Ranal et al., 2006), determined by Equation 4:

$$
\mathrm{Vm}=\frac{\sum_{\mathrm{i}}^{\mathrm{j}} \mathrm{n}_{\mathrm{i}}}{\sum_{\mathrm{i}}^{\mathrm{j}} \mathrm{n}_{\mathrm{i}} \mathrm{t}_{\mathrm{i}}}
$$

where, $\mathrm{Vm}=$ mean germination time, emerged seeds day ${ }^{-1} ; \mathrm{t}_{\mathrm{i}}$ : time between the beginning of the experiment and the $\mathrm{i}$-nth observation (day); ni: germinated seeds in time $\mathrm{t}_{\mathrm{i}}$; and $\mathrm{j}$ : last day of observation.

\subsection{Coefficient of Uniformity of Germination (CUG)}

The germination variability of each seed around its mean time was determined second (Heydecker, 1973; Ranal \& Santana, 2006) (Equation 5):

$$
\mathrm{CUG}=\frac{\sum_{\mathrm{i}}^{\mathrm{j}} \mathrm{n}_{\mathrm{i}}}{\sum_{\mathrm{i}}^{\mathrm{j}}\left(\mathrm{D}_{\mathrm{m}}-\mathrm{D}_{\mathrm{i}}\right)^{2} \cdot \mathrm{n}_{\mathrm{i}}}
$$

where, $\mathrm{n}_{\mathrm{i}}$ : germinated seeds $\mathrm{i}$-nth day; Di: days counted from the experiment installation and until first measurement (i); $\mathrm{D}_{\mathrm{m}}$ : mean of days; and $\mathrm{j}$ : last day of observation.

\subsection{Timson Index (TI)}

Timson (1965) suggested an index based on cumulative daily germination. This measure is based on the number of days required for the germination of weed species. This measure was defined based on the number of days required for seed weed species to complete the germination process, such as cumulative daily germination in 10 days, the totals over the other periods are quoted as $\Sigma 5$ for five days, $\Sigma 20$ for 20 days, and so on, this study was calculated for 7 days (Equation 6):

$$
\mathrm{T}=\sum_{\mathrm{i}=1}^{\mathrm{t}} \operatorname{gi}(\mathrm{t}-\mathrm{j}) \quad(\mathrm{j}=\mathrm{i}-1)
$$

where, T: Timson index, \%.day; gi: percentage of germination accumulated in time interval i; t: total of time intervals of the experiment; and i: time interval between observations. 


\subsection{Modified Timson Index (TIm)}

One way to minimize the effect of the final percentage of germination was proposed by Labouriau \& Pacheco, (1978), proposing to divide the Timson's index by the sum of Germinabilities (gi) (Equation 7):

$$
\operatorname{TIm}=\frac{\sum_{i=1}^{\mathrm{t}} \mathrm{gi}(\mathrm{t}-\mathrm{j})}{\sum_{\mathrm{i}=1}^{\mathrm{t}} \mathrm{gi}} \quad(\mathrm{j}=\mathrm{i}-1)
$$

where, TIm: modified Timson index, \%.day; gi: percentage of germination accumulated in time interval i; t: total of time intervals of the experiment; and i: time interval between observations.

\subsection{Synchronization Index}

Seed germination, in general, is not perfectly synchronized (Ranal \& Santana, 2006), to quantify this variation over time, the synchronization index was determined by Equation 8:

$$
\mathrm{U}=-\sum_{\mathrm{i}}^{\mathrm{j}} \mathrm{f}_{\mathrm{i}} \cdot \log _{2} \mathrm{f}_{1} \quad\left(\mathrm{f}_{\mathrm{i}}=\frac{\mathrm{n}_{\mathrm{i}}}{\sum_{\mathrm{i}}^{\mathrm{j}} \mathrm{n}_{\mathrm{i}}}\right)
$$

where, $\mathrm{f}_{\mathrm{i}}$ : relative frequency of germination; $\mathrm{n}_{\mathrm{i}}$ : germinated seeds, day $\mathrm{i}$; and $\mathrm{j}$ : last day of observation.

From a practical point of view, the lower the value of $U$, the more synchronized will be the seeds germination. The advantage of this index is that its value is not influenced by the total number of germinated seeds, nor by the average time or mean speed of germination. The index is expressed in bits, a binary measure that counts, for example, germinate/does not germinate, on/off (Ranal \& Santana, 2006).

Though, to evaluate the degree of overlap in germination, an index called " $Z$ " was proposed, which produces a number if and only if there are two seeds ending the germination at the same time. Then, $Z=1$ when the germination of all seeds occurs at the same time and $Z=0$ when at least two seeds could germinate, one at a time. Thus, the value of $Z$ measures the germination synchrony, namely, the degree of germination overlap (Equation 9):

$$
\mathrm{Z}=\frac{\sum_{\mathrm{i}}^{\mathrm{j}} \mathrm{C}_{\mathrm{i}, 2}}{\mathrm{~N}} \quad\left(\mathrm{C}_{\mathrm{i}, 2}=\frac{\mathrm{n}_{\mathrm{i}}\left(\mathrm{n}_{\mathrm{i}}-1\right)}{2} \text { and } \mathrm{N}=\frac{\sum_{\mathrm{i}}^{\mathrm{j}} \mathrm{n}_{\mathrm{i}}\left(\sum \mathrm{n}_{\mathrm{i}}-1\right)}{2}\right)
$$

where, $\mathrm{C}_{\mathrm{i}, 2}$ : Germinated seeds sum in time i; ni: germinated seeds, time i; and $\mathrm{j}$ : last day of observation.

\subsection{Germination Curve Analysis}

The cumulative seed germination for each species was adjusted to a polynomial regression and to improve the fit a nonlinear model with a mathematical function known as four-parameter Hill function (El-Kassaby et al., 2008) was used, specifically to measure the germination time and seed dormancy using Germinator software (Joosen et al., 2010) (Equation 10):

$$
\mathrm{y}=\mathrm{y}_{0}+\frac{\mathrm{ax}^{\mathrm{b}}}{\mathrm{c}^{\mathrm{b}}+\mathrm{x}^{\mathrm{b}}}
$$

where, $y$ is the percentage of cumulative germination at time $x, y_{0}$ is the intercept on the $y$-axis, a is the asymptote, or the maximum percentage of cumulative germination, which is equivalent to the germinative capacity, $\mathrm{b}$ is a mathematical parameter that controls the form and the germination curve slope, and c represents the time required to germinate $50 \%$ viable seeds $\left(\mathrm{t}_{50}\right)$ and $\mathrm{x}$ is the time in days.

Germinator software allows the calculation of maximum germination (Gmax: maximum germination, \%), germination rate $\left(\mathrm{t}_{50}\right.$ : time to reach $50 \%$ germination, days), germination uniformity (U7525: germination time between 25 and $75 \%$, days), mean germination velocity $\left(\mathrm{Vm}\right.$, days $\left.{ }^{-1}\right)$ and area under the germination curve (AUC) between time zero and 35 days of this study.

The data collected were statistically analyzed using the program R (Version 3.3) of Knezevic et al. (2007) subjected to the Shapiro-Wilk's statistical tests of normality, analysis of variance and Tukey at the level of significance equal to $5 \%$.

\section{Results}

\subsection{Seed Weight and Moisture Degree}

The weight of 1000 seeds was equal to $0.0307 \mathrm{~g}$ for B. trimera (E1) and $0.0047 \mathrm{~g}$ for B. crispa (E2). The moisture of 1000 seeds was equal to $8.8095 \%$ for $B$. trimera (E1) and $10.5412 \%$ for $B$. crispa (E2).

\subsection{X-ray Adequacy Test}

Regardless the species, the standard procedure to perform the X-ray test followed by the standard germination test (ISTA, 2008), was not appropriate due to the size of the seeds, therefore the number of seeds per box was 
increased from 25 to 200 to guarantee the evaluation of the germination. The analysis of the obtained images allowed to determine the standard size of the seeds, $0.56 \mathrm{~mm}$ long and $0.18 \mathrm{~mm}$ wide for B. crispa (E2), and $0.68 \mathrm{~mm}$ long and $0.28 \mathrm{~mm}$ wide for B. trimera (E1). From 200 seeds, $45.80 \%$ were fully formed, with $56.0 \%$ of normal germinated plants (Table 1), considering this value, indicative of the germination response.

Table 1. Categories of Baccharis trimera (Less.) DC. var. CPQBA-1 seeds according to their internal structure visualized by radiographs in totally formed (TF), partially formed (PF), non-formed (NF) and seed germination, submitted to the X-ray test

\begin{tabular}{lllll}
\hline \multirow{2}{*}{ Class } & \multirow{2}{*}{ Total seeds class (\%) } & \multicolumn{3}{c}{ Germination (\%) } \\
\cline { 3 - 5 } & & PN & PA & NG \\
\hline TF & 45.80 & 56.00 & 6.00 & 38.00 \\
PF & 10.00 & 0.00 & 8.00 & 92.00 \\
NF & 34.00 & 0.00 & 0.00 & 100.00 \\
\hline
\end{tabular}

Note. PN: Normal plants; PA: Abnormal plants; NG: non-germinated plants.

\subsection{Gemination Test}

For B. crispa (E2) seeds, the results were obtained in two lots only, so the percentage of germination ranged between $0.5 \%$ and $1.5 \%$; germination speed index (GSI) between 16 and 24.6 days; mean germination time between 0.06 and 0.04 day $^{-1}$. Considering the low percentage of germination of this species in the research, only the results obtained by the species (E1) were evaluated.

The number of germinated seeds (E1) presented normality in all treatments and when compared by F test did not differ significantly $(\mathrm{P}>0.05)$.

Seed germination (E1) started 18 days after sowing, stabilize at 27 days, totaling 35 days. The percentage of germination from lot 4 exceeded the lots 1 and 2 , followed by the percentage of germination of lot 3 , according to the values obtained from the calculation of the IVG, the mean number of days for seeds germination of the cultivar (E1) was 27 days on average for all lots. The seeds from lot 2 were the ones with the lowest mean germination time (IVG $=25$ days) and, consequently, the mean germination speed was higher for the seeds of this lot $\left(\mathrm{Vm}=0.040 \mathrm{day}^{-1}\right)$. On average, the seeds, regardless the lot, presented germination time of 27.34 days, with a germination speed of 0.037 day $^{-1}$ (Table 2).

The value obtained in Equation 2 was influenced by the mean germination time and consequently the germination speed of the seeds. The germination dispersion over time, expressed by the coefficient of variation of time $(\mathrm{CVt})$ and the coefficient of uniformity of germination (CUG), showed that the germination of the seeds was homogeneous among the lots, since low values were recorded for the coefficient of variation of time and high value for the coefficient of uniformity (Table 2). Taking the results of the velocity of emergency (VE), the Timson's index (TI) and the modified Timson's index (TIm), it is possible to verify that these measures indicate the same sequence determined by the calculation of the mean germination time $(\mathrm{Vm})$, for the lots with higher and lower speed. Thus, the seeds from lot 4 were classified as vigorous and those from 2, although the lower final percentage of germination, had the mean germination time higher than the results of the seeds from the other lots, as confirmed by Tmod (Table 2).

Table 2. Parameters characterizing seed germination of Baccharis trimera (Less.) DC. CPQBA-1

\begin{tabular}{lllllllllll}
\hline Lot & G $(\%)$ & IVG & CVt $(\%)$ & $\begin{array}{l}\text { VM } \\
\left(\text { emerged seeds day }^{-1}\right)\end{array}$ & U & Z & VE & CUG & $\begin{array}{l}\text { TI } \\
\left(\% \text { day }^{-1}\right)\end{array}$ & $\begin{array}{l}\text { Tim } \\
\left(\% \text { day }^{-1}\right)\end{array}$ \\
\hline 1 & 34.00 & 27.559 & 21.512 & 0.036 & 2.057 & 0.254 & 1.943 & 0.029 & 61.000 & 1.794 \\
2 & 44.00 & 25.023 & 21.670 & 0.040 & 2.156 & 0.235 & 2.514 & 0.034 & 91.500 & 2.080 \\
3 & 46.50 & 28.022 & 21.961 & 0.036 & 2.082 & 0.260 & 2.657 & 0.027 & 83.500 & 1.796 \\
4 & 59.00 & 28.754 & 20.273 & 0.035 & 1.930 & 0.295 & 3.371 & 0.030 & 100.000 & 1.695 \\
\hline Mean & 45.87 & 27.339 & 21.354 & 0.037 & 2.056 & 0.261 & 2.621 & 0.030 & 84.000 & 1.841 \\
CV (\%) & 19.41 & 5.135 & 3.018 & 5.374 & 3.969 & 8.275 & 19.411 & 9.403 & 17.267 & 7.800 \\
\hline
\end{tabular}

Note. G: Germination rate; IVG: Rate of germination; CVt: coefficient of variation of germination time; VM: Average speed of germination; U: synchronization index; $\mathrm{Z}$ : degree of germination overlap; VE: Speed of germination; CUG: coefficient of uniformity of germination; TI: Timson Index; TIm: Timson index modified. 
The uncertainty results far from zero $(U \geq 2.056)$ and $Z$ less than one $(Z \leq 0.261)$ indicate that seeds germination occurred well-distributed in time; that way, the synchronization of seeds germination from lot 4 exceeded the synchronization of the seeds germination from other lots.

\subsection{Cultivar CPQBA-1 (E1) Seed Germination Curve Analysis}

The relative frequencies of germination demonstrate that the germination results of all seed lots of cultivar CPQBA-1 show the same tendency (Figure 1), reaching maximum germination at 35 days, except for seeds from lot 2 , that reaches $50 \%$ of the accumulated germination at 25 days and maximum at 27 days, decreasing until the final evaluation. The distribution of the seed germination frequency in relation to the time of the cultivar CPQBA-1 (E1) probably was since the seeds from lot 2 have germinated earlier (Figure 2), which may affect the germination speed calculation.

The results of seed germination, lots 1, 2, 3 and 4 were adjusted to the quadratic regression model (Table 3), allowing the use of the curve presented in Figure 2 to express the germination ratio of the seeds as a function of time.
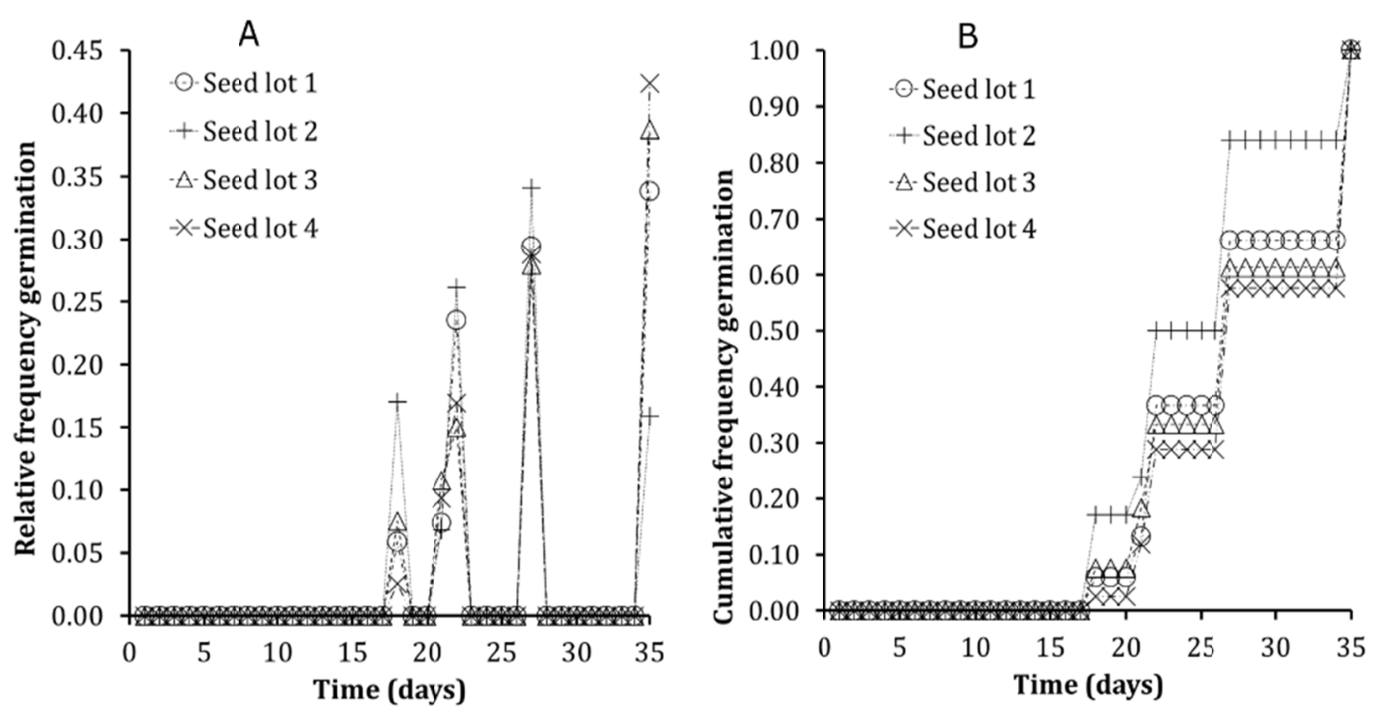

Figure 1. Distribution of relative (A) and accumulated (B) frequency of seed germination of Baccharis trimera (Less.) DC. CPQBA-1

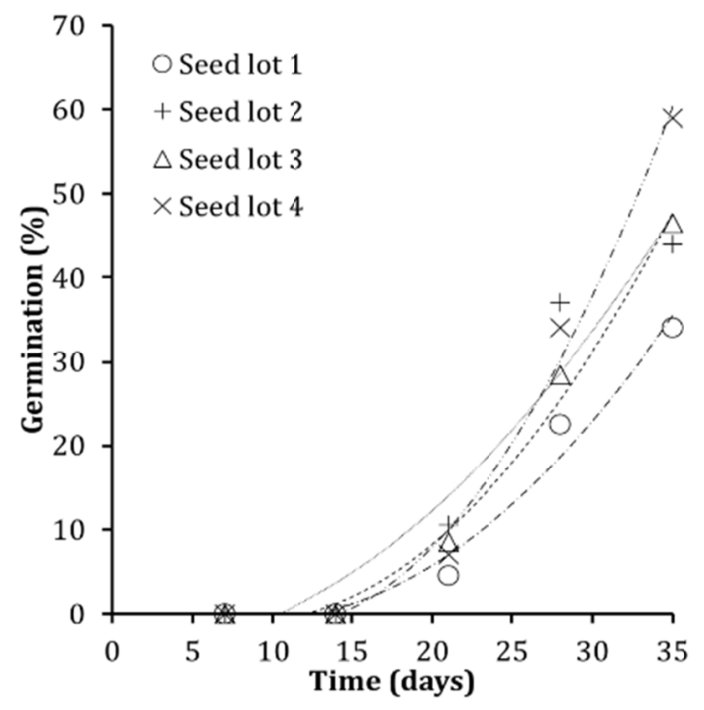

Figure 2. Quadratic model fitted to cumulative germination curves of Baccharis trimera (Less.) DC. CPQBA-1 
Table 3. Quadratic regression models for percentages of germination $(\% \mathrm{G})$ as a function of germination time $(\mathrm{t})$, for Baccharis trimera (Less.) DC seeds CPQBA-1

\begin{tabular}{llll}
\hline Lot & Regression equations & $\mathrm{R}^{2}$ & Significance \\
\hline 1 & $\% \mathrm{G}=0.051 \mathrm{t}^{2}-0.8191 \mathrm{t}+2.1466$ & 0.9481 & $6.222 \mathrm{e}^{-13} * * *$ \\
2 & $\% \mathrm{G}=0.0624 \mathrm{t}^{2}-0.7908 \mathrm{t}+1.2684$ & 0.9027 & $2.443 \mathrm{e}^{-10 * * *}$ \\
3 & $\% \mathrm{G}=0.0686 \mathrm{t}^{2}-1.0994 \mathrm{t}+2.8969$ & 0.9663 & $1.022 \mathrm{e}^{-14} * * *$ \\
4 & $\% \mathrm{G}=0.0898 \mathrm{t}^{2}-1,5524 \mathrm{t}+4.4997$ & 0.9657 & $1.205 \mathrm{e}^{-14} * * *$ \\
\hline
\end{tabular}

Note. $\mathrm{R}^{2}$ : Coefficient of determination. ***: Fisher's exact test, $\mathrm{P}=0.099$.

Although all the equations presented high $\mathrm{R}^{2}$, the quadratic model is characterized by a low quality of adjustment, by increasing at lower rates over time, until reaching the maximum point, when starts to decrease. As the percentages of germination used to calculate these curves are always accumulated, the decrease predicted by the model after the maximum germination has been reached (Ranal et al., 2006).

The results from Germinator showed that the maximum germination obtained (Gmax, \%) with 200 seeds of cultivar B. trimera (E1), was $59 \%$ for lot 4 , lot 2 presented the shortest time to reach $50 \%$ of germination, 22.59 days, conditioning the smaller uniformity (U7525) and the lowest germination velocity mean (Vm) (Table 4), due to the shape and slope of the curve (Figure 2, where lot 2 presented the second largest area under curve (AUC).

It was observed for lot 1, the smaller uniformity $\mathrm{U} 7525$ and the lowest germination velocity mean (Vm), however due to the curve slope and shape, it was verified the smaller area under curve (AUC) (Figure 4). The results of the germinative performance and the Hill function parameters (Table 5) allow us to appreciate that the Hill function presents a higher correlation coefficient of seedling twinning of $B$. trimera (E1) when compared to the quadratic adjustment.

Table 4. Parameters estimated by the Hill function for seed germination of Baccharistrimera (Less.) DC. CPQBA-1

\begin{tabular}{llllll}
\hline Lot & $\mathrm{G}_{\max }(\%)$ & $\mathrm{t}_{50}$ (days) & $\mathrm{U}_{7525}$ (days) & $\mathrm{Vm}\left(\right.$ days $\left.^{-1}\right)$ & AUC \\
\hline 1 & $34 \%$ & 24.550 & 6.026 & 23.49 & 3.46 \\
2 & $44 \%$ & 22.597 & 4.826 & 22.54 & 5.34 \\
3 & $47 \%$ & 24.872 & 6.689 & 23.20 & 4.58 \\
4 & $59 \%$ & 25.545 & 6.361 & 23.80 & 5.44 \\
\hline
\end{tabular}

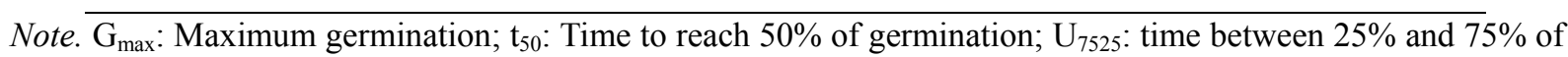
germinated seeds; AUC: Area under the curve.

Table 5. Values of the Hill function parameters for seed germination of Baccharis trimera (Less.) DC. CPQBA-1

\begin{tabular}{llllll}
\hline \multirow{2}{*}{ Lot } & \multicolumn{5}{c}{ Hill equation parameters } \\
\cline { 2 - 5 } & $y_{o}$ & $a$ & $b$ & $\mathrm{R}^{2}$ \\
\hline 1 & 0.00 & 0.3400 & 8.9740 & 24.5498 & 0.9865 \\
2 & 0.00 & 0.4399 & 10.3067 & 22.5968 & 0.9869 \\
3 & 0.00 & 0.4650 & 8.1939 & 24.8715 & 0.9899 \\
4 & 0.00 & 0.5900 & 8.8460 & 25.5454 & 0.9890 \\
\hline
\end{tabular}

Note. $y_{0}$ : the intercept on the $y$-axis; $a$ : \% of cumulative maximum germination; $b$ : mathematical parameter of the form and slope of the germination curve; $c$ : represents the time required to germinate $50 \%$ viable seeds $\left(t_{50}\right)$.

Experimental data of cumulative germination in relation to the adjusted values obtained by the Hill function and estimated by the quadratic regressions (Figure 3) presented a satisfactory fit for all lots of the cumulative germination values adjusted by the Hill function, which confirms the plasticity of this model to the data from B. trimera (E1). 

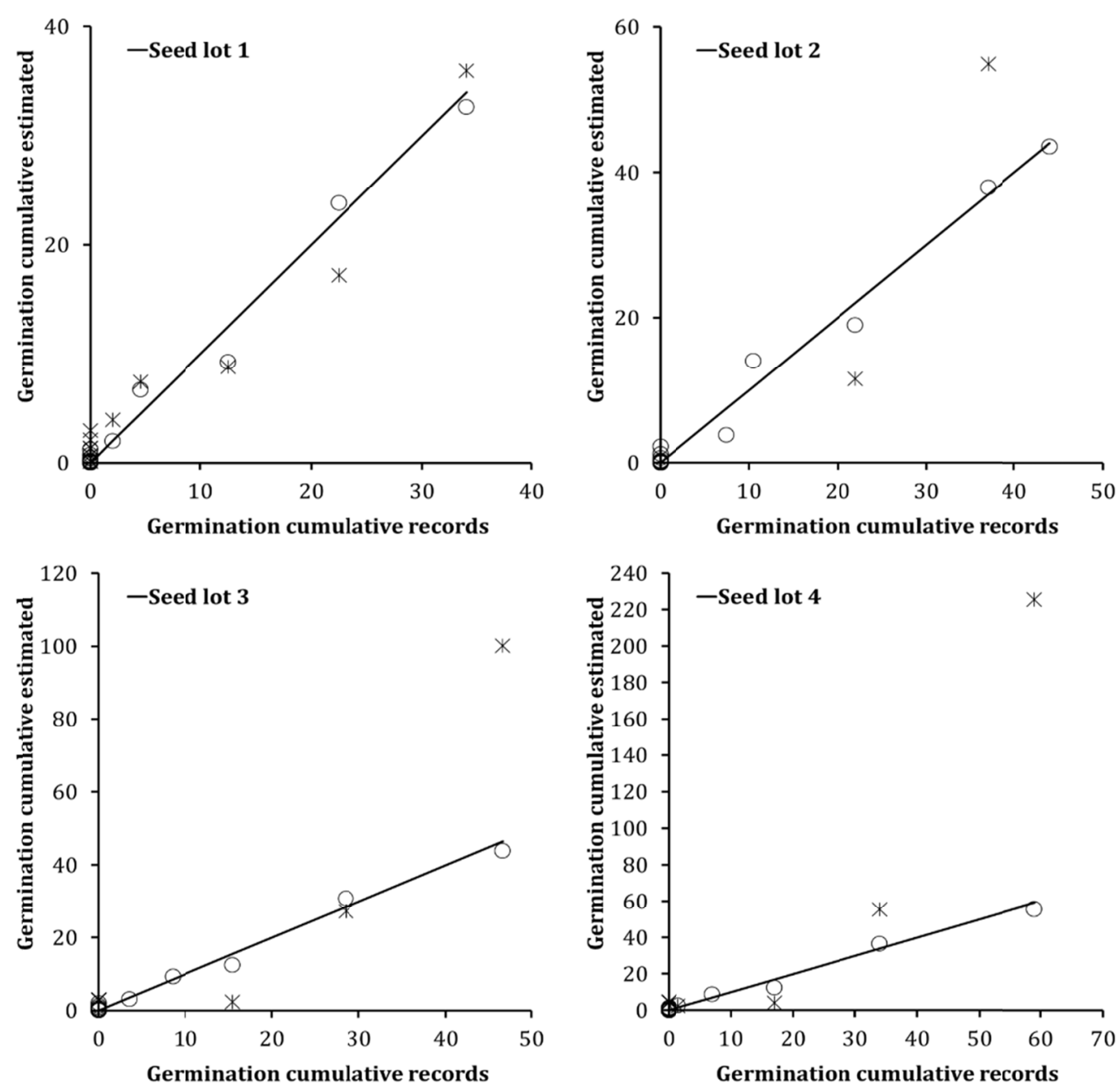

Figure 3. Cumulative germination of the seeds of Baccharis trimera (Less.) DC. CPQBA-1, of the experimental data of the adjusted values obtained by the Hill function $(\circ)$ and estimated by the quadratic regressions ( ) 

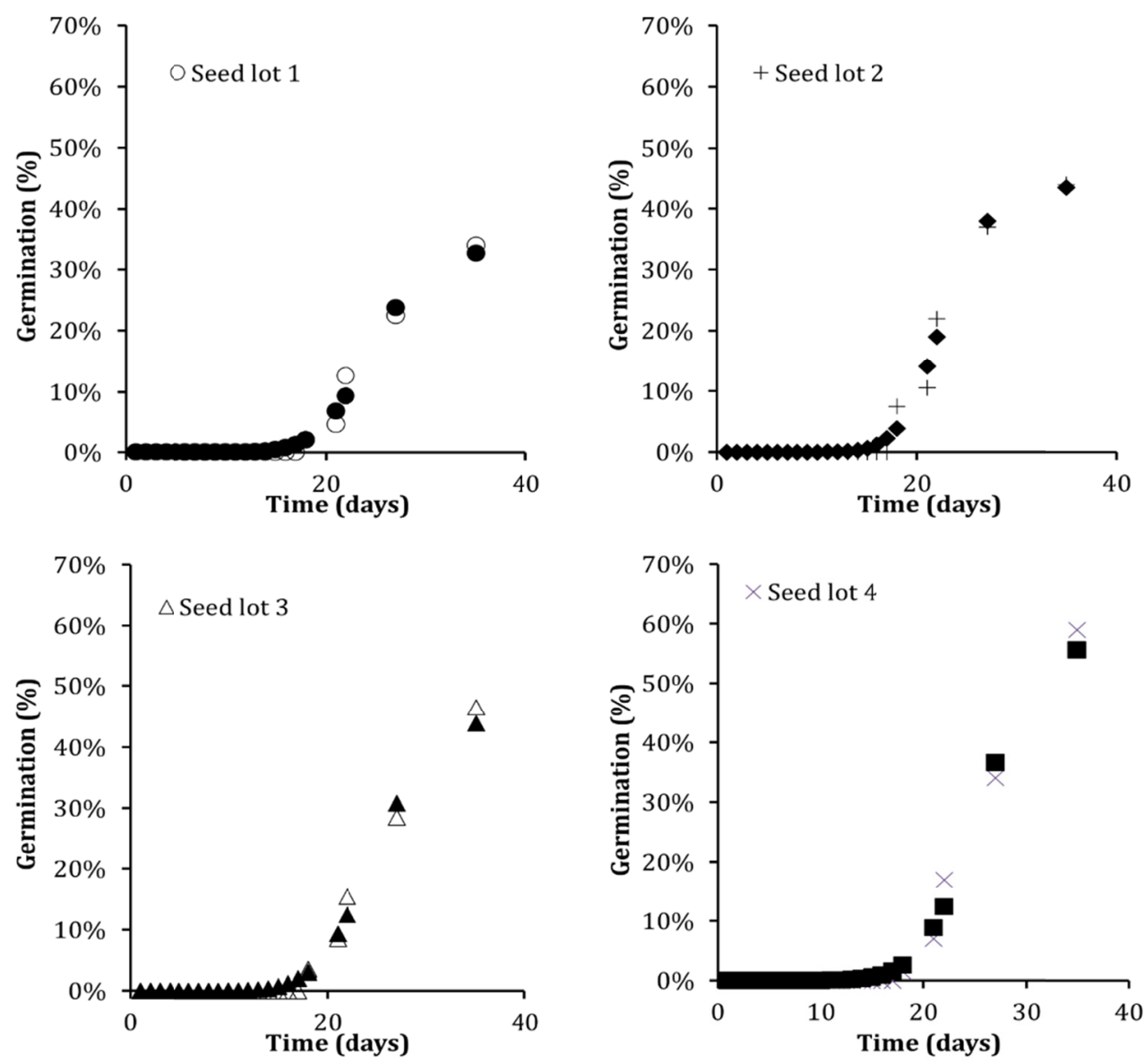

Figure 4. Comparison of observed germination $(\circ,+, \Delta, \times)$ with respect to values estimated by the Hill function $(\bullet, \bullet, \boldsymbol{\Delta}, \boldsymbol{\square})$ of Baccharis trimera (Less.) DC seeds. CPQBA-1

Hill's model was superior than the quadratic regressions, allowing to estimate cumulative germination values in time. Quadratic regressions were not adequate to characterize the results of carqueja seed germination data, once had described a gradual incremental progression that did not allow estimating the final percentage of cumulative germination.

\section{Discussion}

The obtained results showed that weight and moisture degree of $B$. trimera (E1) and B. crispa (E2) seeds are in the ideal pattern for harvesting and storing seeds of orthodox species. Considering that at the end of the development and maturation process, the plants were naturally dried because they were at the end of the phenological cycle in such way that the canopy contained low moisture degree, about 5 to $10 \%$ (Kermode, 1997; Luz \& Coimbra, 2014).

The $\mathrm{x}$-ray test was not adequate to evaluate the developmental state of the carqueja seed structures. However, normal seed analysis is subjective and difficult to evaluate (Onwimol et al., 2016).

The low germination percentage of $B$. crispa (E2) may be due to the smaller weight and size, as it happens with some small orchid seeds with no possibility of storing nutrients (Kananont et al., 2010; H. N. Rasmussen \& F. N. Rasmussen, 2014), reducing their germination capacity. Measuring germination can provide valuable information about beginning, rate, uniformity and final percentage of germination. For example, two seed lots may have the same percentage of germination, but different velocity or uniformity (Soltani et al., 2015), as observed in the results.

The results of the present study showed that the $\mathrm{t}_{50}$ estimated by Hill's model for seed germination of $B$. trimera (E1) was a good parameter to classify the vigor of these seeds, as well as it was successful in the classification of bean vigor (feijão mungo) (Onwimol et al., 2016) possibly due to the structural details of the normal seedlings. However, the mean velocity of emergence of the radicle was a successful parameter in the classification of 
species vigor, such as corn (Khajeh-Hosseini et al., 2010; Matthews et al., 2009), cabbage (Demir et al., 2008), watermelon, melon and cucumber (Mavi et al., 2010).

The behavior of germination dispersion over time showed that, the higher the value of CUG, the more concentrated in time the germination of the seeds.

It was confirmed the existence of new alternatives for the evaluation of the vigor of carqueja seeds, represented by emergency dispersion over time through the coefficient of variation of time, coefficient of emergency uniformity and the possibility of inclusion in the vigor analysis of Baccharis seeds from the emergency velocity indexes, Timson's index and Timson modified index to verify the average velocity of emergency.

The seeds of $B$. trimera (E1) have a superior germination than the cultivar $B$. crispa (E2). The enhancement of $B$. trimera (E1) had an influence on the tests due to improvements in seed morphology and size, suggesting that larger seed size samples may have a higher value in terms of propagation of these species.

The described procedures seek to present a methodology to evaluate the germination of this microseed. The value of velocity of emergency VE is also influenced by the germination uniformity, verifying a vigor index of the evaluated lots, the elevated value of the uniformity coefficient of germination CUG showed that the seeds germination was concentrated in the time. The germination variability of each lot around its average time, was calculated as the inverse of the variance of the average germination times, presented as an adequate index for the characterization of the species germination. The synchronization or uncertainty index allowed quantifing the variation of the germination over time. Average germination velocity determined with experimental data approached the values calculated by Germinator package, with a satisfactory adjustment, proving that it can be used to carry out the analysis of general data of cumulative germination of these species. This would not be appropriate for all crops, but experience suggests that predictive regression equations could be developed for cultivars or groupings of Brassica species and grain legumes (Demir et al., 2008; Matthews et al., 2009; Onwimol et al., 2016)

Germination tests performed to identify seed vigor are very important in agricultural production because they facilitate planning of farmers' productive activities (Onwimol et al., 2016). Seeds viability is a matter of great concern, and measures to maintain the germination efficiency of stored seeds have significant economic implications. However, future studies, based on experimental approaches using modeling, should be conducted to model the growth of these microplantules and their development under different planting conditions.

\section{References}

Abad, M. J., \& Bermejo, P. (2007). Baccharis (Compositae): A review update. Arkivoc, 2007(7), 76-96.

Arruda, N., Silvio Moure, C., \& Gomes Junior, F. G. (2018). Radiographic analysis for the evaluation of polyembryony in Swingle citrumelo seeds. Journal of Seed Science, 40(2), 118-126. https://doi.org/10.1590/ 2317-1545v40n2175172

Asgarpour, R., Ghorbani, R., Khajeh-Hosseini, M., Mohammadvand, E., \& Chauhan, B. (2015). Germination of Spotted Spurge (Chamaesyce maculata) Seeds in Response to Different Environmental Factors. Weed Science, 63(2), 502-510. https://doi.org/10.1614/WS-D-14-00162.1

Bai, Y., \& Romot, J. (1995). Seedling emergence of Artemisia frigida in relation to hydration-dehydration cycles and seedbed characteristic. Journal of Arid Environment, 30(1), 57-65. https://doi.org/10.1016/S0140-196 3(95)80038-7

Bazin, J., Batlla, D., Dussert, S., El-Maarouf-Bouteau, H., \& Bailly, C. (2011). Role of relative humidity, temperature, and water status in dormancy alleviation of sunflower seeds during dry after-ripening. Journal of Experimental Botany, 62(2), 627-640. https://doi.org/10.1093/jxb/erq314

Bewley, J. D., \& Black, M. (1994). Seeds (pp. 1-33). Springer, New York, USA. https://doi.org/10.1007/ 978-1-4899-1002-8_1

Bonner, F. T. (1984). Tolerance limits in measurement of tree seed moisture. Seed Science Technology, 30(1), $17-27$.

Budel, J. M., Duarte, M. R., Döll-Boscardin, P. M., Farago, P. V., Matzenbacher, N. I., Sartoratto, A., Sales, \& Maia, B. H. L. N. (2012). Composition of essential oils and secretory structures of Baccharis anomala, B. megapotamica and B. ochracea. Journal of Essential Oil Research, 24(1), 19-24. https://doi.org/10.1080/ 10412905.2012 .645634 
Campos, F. R., Bressan, J., Jasinski, V. C. G., Zuccolotto, T., Silva, L. E., \& Cerqueira, L. B. (2016). Baccharis (Asteraceae): Chemical Constituents and Biological Activities. Chemistry and Biodiversity, 13(1), 1-17. https://doi.org/10.1002/cbdv.201400363

Cardoso, J. C., Teixeira, J. A., \& Silva, D. (2013). Micropropagation of Zeyheria montana Mart. (Bignoniaceae), an endangered endemic medicinal species from the Brazilian cerrado biome. In Vitro Cellular \& Developmental Biology_Plant, 49(6), 710-716. https://doi.org/10.1007/s11627-013-9558-0

de Oliveira, R. N., Rehder, V. L. G., Santos Oliveira, A. S., Júnior, Í. M., de Carvalho, J. E., de Ruiz, A. L., ... Allegretti, S. M. (2012). Schistosomamansoni: In vitro schistosomicidal activity of essential oil of Baccharis trimera (less) DC. Experimental Parasitology, 132(2), 135-143. https://doi.org/10.1016/ j.exppara.2012.06.005

Demir, I., Mavi, K., Kenanoglu, B. B., \& Matthews, S. (2008). Prediction of germination and vigour in naturally aged commercially available seed lots of cabbage (Brassica oleracea var. capitata) using the bulk conductivity method. Seed Science and Technology, 36(3), 509-523. https://doi.org/10.15258/sst.2008. 36.3.01

Edwards, T. I. (1932). Temperature relations of seed germination. The Quarterly Review of Biology, 7(4), 428-443. https://doi.org/10.1086/407036

Ferreira Marques, F. R., Meiado, M. V., MariaReal de Castro, C., Lins de Oliveira, Campos, M., Mendes, K. R., ... Pompelli, M. F. (2015). GerminaQuant: A new tool for germination measurements 1. Journal of Seed Science, 37(3), 248-255. https://doi.org/10.1590/2317-1545v37n3145605

Fukuda, M., Ohkoshi, E., Makino, M., \& Fujimoto, Y. (2006). Studies on the Constituents of the Leaves of Baccharis dracunculifolia (Asteraceae) and their Cytotoxic Activity. Chemical and Pharmaceutical Bulletin, 54(10), 1465-1468. https://doi.org/10.1248/cpb.54.1465

García, D., Furlan, M. R., \& Ming, L. C. (2018). Baccharis trimera (Less.) DC. Medicinal and Aromatic Plants of South America, 1(1), 129-138. https://doi.org/10.1007/978-94-024-1552-0_10

Gené, R. M., Cartañá, C., Adzet, T., Marín, E., Parella, T., \& Cañiguera, S. (1996). Anti-Inflammatory and Analgesic Activity of Baccharistrimera: Identification of its Active Constituents. Planta Medica, 62(3), 232-235. https://doi.org/10.1055/s-2006-957866

Heydecker, W. (1973). Glossary of terms. Seed Ecology (pp. 553-557).

ISTA. (2008). Method Validation Reports on Proposed Changes to the ISTA International Rules for Seed Testing ISTA Method Validation Reports 01-2008. Zürichstrasse.

Joosen, R. V. L., Kodde, J., Willems, L. A. J., Ligterink, W., Van Der Plas, L. H. W., \& Hilhorst, H. W. M. (2010) Germinator: A software package for high-throughput scoring and curve fitting of Arabidopsis seed germination. The Plant Journal, 62(1), 148-159. https://doi.org/10.1111/j.1365-313X.2009.04116.x

Kananont, N., Pichyangkura, R., Chanprame, S., Chadchawan, S., \& Limpanavech, P. (2010). Chitosan specificity for the in vitro seed germination of two Dendrobium orchids (Asparagales: Orchidaceae). Scientia Horticulturae, 124(2), 239-247. https://doi.org/10.1016/j.scienta.2009.11.019

Khajeh-Hosseini, M., Nasehzadeh, M., \& Matthews, S. (2010). Rate of physiological germination relates to the percentage of normal seedlings in standard germination tests of naturally aged seed lots of oilseed rape. Seed Science and Technology, 38(3), 602-611. https://doi.org/10.15258/sst.2010.38.3.08

Labouriau, L. G., \& Agudo, M. (1987). On the physiology of seed-germination in Salvia hispanica L. Temperature effects. Annals of the Brazilian Academy of Sciences, 59(1), 37-56.

Labouriau, L. G., \& Osborn, J. H. (1984). Temperature dependence of the germination of tomato seeds. Journal of Thermal Biology, 9(4), 285-294. https://doi.org/10.1016/0306-4565(84)90010-X

Labouriau, L. G., \& Pacheco, A. (1978). On the frequency of isothermal germination in seeds of Dolichos biflorus L. Plant \& Cell Physiology, 19(3), 507-512. https://doi.org/10.1093/oxfordjournals.pcp.a075620

Labouriau, L. G., \& Valadares, M. E. B. (1976). On the germination of seeds Calotropis procera (Ait.) Ait.f. Annals of the Brazilian Academy of Sciences, 48(2), 263-284.

Maguire, J. D. (1962). Speed of germination-aid in selection and evaluation for seedling emergence and vigor. Crop Science, 2(1), 176-177. https://doi.org/10.2135/cropsci1962.0011183X000200020033x 
Matthews, S., Demir, I., Celikkol, T., Kenanoglu, B. B., \& Mavi, K. (2009). Vigour tests for cabbage seeds using electrical conductivity and controlled deterioration to estimate relative emergence in transplant modules. Seed Science and Technology, 37(3), 736-746. https://doi.org/10.15258/sst.2009.37.3.20

Mavi, K., Demir, I., \& Matthews, S. (2010). Mean germination time estimates the relative emergence of seed lots of three cucurbit crops under stress conditions. Seed Science and Technology, 38(1), 14-25. https://doi.org/ 10.15258/sst.2010.38.1.02

Melo, L. D. F. A., Melo Júnior, J. L. A., Ferreira, V. M., Neto, J. C. A., \& Neves, M. I. R. S. (2018). Biometric characterization and seed germination of giant mimosa (Mimosa bimucronata (DC) O. Kuntze). Australian Journal of Crop Science, 12(1), 108-115. https://doi.org/10.21475/ajcs.18.12.01.pne773

Nichols, M. A. (1968). Two approaches to the study of germination data. Proceedings International Seed Test Association, 33(3), 531-540.

Oliveira, A. C. P., Endringer, D. C., Amorim, L. A. S., Brandão, M. D. G. L., \& Coelho, M. M. (2005). Effect of the extracts and fractions of Baccharistrimera and Syzygiumcumini on glycaemia of diabetic and non-diabetic mice. Journal Ethnopharmacology, 102(3), 465-469. https://doi.org/10.1016/j.jep.2005.06.025

Onwimol, D., Chanmprasert, W., Changsee, P., \& Rongsangchaichareon, T. (2016). Seed vigor classification using analysis of mean radicle emergence time and single counts of radicle emergence in rice (Oryza sativa L.) andmung bean (Vigna radiata (L.) Wilczek). Agricultural and Natural Resources, 50(5), 345-350. https://doi.org/10.1016/j.anres.2016.12.003

Prado-Alves, M. V., Von Pinho, E. V. R., Santos, H. O., Alves, G. C. P., Carvalho, M. L. M., \& Bustamante, F. O. (2018). Image analysis, quality and maturation of jiló (Solanum gilo) seeds. Agrociencia, 52(2), 267-278.

Rabelo, A. C. S., \& Costa, D. C. (2018). A review of biological and pharmacological activities of Baccharis trimera. Chemico-Biological Interactions, 296(1), 65-75. https://doi.org/10.1016/j.cbi.2018.09.002

Ranal, M. A., \& Santana, D. G. (2006). How and why to measure the germination process? Brazilian Journal of Botany, 29(1), 1-11. https://doi.org/10.1590/S0100-84042006000100002

Rasmussen, H. N., \& Rasmussen, F. N. (2014). Seedling mycorrhiza: A discussion of origin and evolution in Orchidaceae. Botanical Journal Linnean Society, 175(3), 313-327. https://doi.org/10.1111/boj.12170

Rossi, M. L., Souza, E. H., Graner, E. M., Almeida, M., \& Martinelli, A. P. (2018). Post-seminal development and morphoanatomy of vegetative and reproductive organs in Stevia rebaudiana (Bert.) Bertoni (Asteraceae). Annals of the Brazilian Academy of Sciences, 90(2), 2167-2177. https://doi.org/10.1590/ 0001-3765201820170587

Sako, Y., Mcdonald, M. B., Fujimura, K., Evans, A. F., \& Bennett, M. A. (2001). A system for automated seed vigour assessment. Seed Science and Technology, 29(3), 625-636.

Santana, D. G., Lobo, G. A., Salomão, A. N., \& Pereira, V. J. (2016). Robustness of germination analysis methods for Copaifera langsdorffii desf. (Fabaceae) seeds. Bioscience Journal, 32(1), 160-171. https://doi.org/10.14393/BJ-v32n1a2016-29425

Soltani, E., Ghaderi-Far, F., Baskin, C. C., \& Baskin, J. M. (2015). Problems with using mean germination time to calculate rate of seed germination. Australian Journal of Botany, 63(8), 631-635. https://doi.org/10.1071/ BT15133

Souza, A. G., Smiderle, O. J., \& Bianchi, V. J. (2018). Biometric characterization and morphophysiological quality of peach rootstock seeds using images of their seedling vigor. Recent Patents on Food, Nutrition and Agriculture, 9(1), 65-73. https://doi.org/10.2174/2212798410666180426155013

Tanabata, T., Shibaya, T., Hori, K., Ebana, K., \& Yano, M. (2012). SmartGrain: High-Throughput Phenotyping Software for Measuring Seed Shape through Image Analysis. Plant Physiology, 160(4), 1871-1880. https://doi.org/10.1104/pp.112.205120

Torres, L. M. B., Gamberini, M. T., Roque, N. F., Lima-Landman, M. T., Souccar, C., \& Lapa, A. J. (2000). Diterpene from Baccharis trimera with a relaxant effect on rat vascular smooth muscle. Phytochemistry, 55(6), 617-619. https://doi.org/10.1016/S0031-9422(00)00223-5 


\section{Copyrights}

Copyright for this article is retained by the author(s), with first publication rights granted to the journal.

This is an open-access article distributed under the terms and conditions of the Creative Commons Attribution license (http://creativecommons.org/licenses/by/4.0/). 